\title{
TRANSFERABILITY OF GREENCITIES EXPERIENCES \\ FOR SUSTAINABLE URBAN PLANNING
}

DOI: http://dx.doi.org/10.18509/GBP.2015.17

UDC: 712.25:911.375

\author{
Dr. Riccardo Privitera \\ Dr. Daniele La Rosa \\ Department of Civil Engineering and Architecture, University of Catania, Italy
}

\begin{abstract}
During the last decades new developments, retrofitting and urban regeneration projects in most of European green cities have been designed according to high level of Urban Design Solutions (UDS) such as green spaces networks, low-carbon mobility systems, mixed land uses, public facilities/services and new jobs. Integration of these UDS to water/waste and renewable energy management systems has shown an effective contribution to urban and environmental quality and sustainability. Even though these successfully experiences provided a considerable amount of valuable UDS, their suitability to be transferred in urban contexts characterized by different environmental, morphological, socio-economic and cultural conditions has not been systematically investigated. This paper proposes a method for evaluating the transferability of several UDS that have been applied in a set of fifteen European green cities to urban contexts of Southern Italy, where socio-economic, environmental, geographical, and cultural conditions are different. The method is based on three different steps. First, UDS are identified and grouped within a matrix in three strategic categories (procedures and economic aspects, urban quality, energy and environment). The second step checks the suitability of these different UDS to be transferred according to six different criteria: climate and geography, mobility/green/facilities equipment, water/waste/energy grids equipment, norms and regulations, urban management policies, social and cultural aspects. The third step is the evaluation of the transferability of UDS based on a survey conducted through web-interviews to Italian national experts in the field of urban planning. Contrary to the expectations, results show that a very high percentage of UDS could be transferred to the southern Italy contexts and that the transferability is more influenced by lack of urban management policies than climatic or geographical features.
\end{abstract}

Keywords: green cities, urban design solutions, urban sustainability, transferability

\section{INTRODUCTION}

In the European Union almost $75 \%$ of the population lives in cities and is responsible of the $69 \%$ of the greenhouse gases emission [1]. The European Union is thus committed to make its cities more sustainable [2]. The idea of cities as sustainable ecosystems is based on the principles of safeguard of water, soils, and biodiversity, as well as reduction of energy consumption and $\mathrm{CO}_{2}$ emission and it is strictly intertwined to climate change adaptation and mitigation measures [3]. These new green cities are designed with the aim of creating a habitat for people oriented to the minimization of waste output and pollution [4]. Green cities have clean air and water, are resilient in the face of natural disasters, run a low risk of major infectious disease outbreaks, encourage green behavior, and have a relatively small ecological impact [5]. According to these objectives, during the last few decades central-northern European green cities developed several urban development 
projects and produced an effective contribution to environmental quality and sustainability of urban contexts [6]. These experiences provided a valuable set of Urban Design Solutions (UDS) that have been applied to buildings (bioclimatic architecture, passive solar systems, photovoltaic and solar panels), at district level (green spaces networks, low-carbon mobility systems, mixed land uses) and at urban scale (water/waste and renewable energy plants and grids management systems). Despite the relevant outcomes in central-northern Europe, transferability of UDS to urban contexts characterized by different environmental, morphological, socio-economic and cultural conditions has not been systematically investigated. This paper proposes a method for assessing conditions of transferability of UDS from a selected set of fifteen European green cities to Southern Italy urban contexts. The fundamental assumption of this study is that transferability is only predictable with a deep knowledge of conditions that enable the development of the UDS. Indicators such as size city, population density, urban sprawl, or even combinations of these, have shown to be unable to reflect the complexity involved [7].

\section{MATERIALS AND METHOD}

The proposed method is based on three different analytical phases. The first step was the analysis of the UDS developed in the studied set of green cities. The survey was conducted on European urban sustainability experiences that took place over the past two decades [6], [8], [9]. Particularly fifteen green cities characterized by different types of development (urban regeneration, retrofitting, new development), size of the development area, and number of inhabitants were analyzed (Table 1). SaragozaValdespartera excepted, these cities are located in central-northern Europe and has experienced several urban planning strategies and proposal of UDS (Figure 1). In order to deal with their complexity and variety, UDS were grouped into three strategic categories (procedural and economic aspects, urban spaces quality, energy and environment) and then sub-divided into different strategies (from A to J, see Table 2). The second step was the assessment of the transferability of UDS from European green cities to the southern Italy cities based on the following six criteria: geographical-climatic features, infrastructures equipment/efficiency (mobility, green infrastructure, real estate), network systems equipment/efficiency (water, energy, waste), norms and regulations, urban management, socio-cultural features. These six criteria have been defined as following.

Geographical-climatic features: transferability of UDS depends on the evaluation of geographical aspects such as specific morphological asset of the site (plain, hill, mountain), altitude, existing water bodies (lakes, rivers, sea), and climatic aspects that can take into account local temperatures, humidity, sunshine, rainfall, wind power; Infrastructure equipment/efficiency: high levels of equipment/performance of these network systems represent a key-condition for the transferability of UDS. Transferability depends on the evaluation of the existence and maintenance conditions of roads, parking lots, and pedestrian-cycle paths, general conditions of public transportation, green infrastructure and real estate;

Network systems equipment/efficiency: transferability depends on the evaluation of the systems equipment levels and their efficiency (adopted technologies, resulting air pollution); evaluation of the energy demand and the production of resources to be used within the waste and water cycles; evaluation of the gap between the amount of resources used within existing energy plants and amount of the remaining resources; design and 
implementation of new small energy plants at local scale (lower costs, size and construction time);

Norms and regulations: local, regional, and national legal framework represents the main constrain to be taken into account in the perspective of the transferability of the UDS. A comparison of the different legal frameworks is fundamental to cope with differences among socio-legal systems;

Urban management: transferability depends on the evaluation of specific political features in terms of capacity of local administrators to lead urban transformation actions. Transferability could be evaluated taking into account their previous experiences in the field of urban innovation actions related to community involvement capacity;

Socio-cultural features: the capacity of a local context to provide information and knowledge, to involve community into the urban transformation process influences the transferability of innovative practices. Transferability could be evaluated taking into account potential interests on urban transformation projects by local/external developers under the public control.

The above listed criteria have been chosen in order to investigate the features of specific urban contexts to be checked for potential transferability. Particularly, southern Italy cities are often characterized by very high annual mean temperatures and low levels of rainfall, lack of public green spaces and public transportation, low quality levels of sustainable mobility infrastructures (pedestrian and bike paths), lack of plants and grids for producing and provisioning renewable resources energy [10].

Table 1. List of the fifteen analyzed European green cities.

\begin{tabular}{|c|c|c|c|c|}
\hline Location & $\begin{array}{c}\text { Type of } \\
\text { development }\end{array}$ & Timeline & Area (Ha) & Inhabitants \\
\hline Sutton-Bedzed & new development & $2000-2002$ & 1,8 & 200 \\
\hline Linz-Solar City & new development & 1995-on going & 9,6 & 6.000 \\
\hline Helsinki-Eco-Viikki & urban rigeneration & $1995-2010$ & 13,3 & 5.500 \\
\hline Middlesbrough-Middlehaven & urban rigeneration & $2003-2030$ & 20 & 2.300 \\
\hline Malmö-Western Harbour & urban rigeneration & 1998-on going & 30 & 4.600 \\
\hline Malmö-Augustenborg & retrofitting & $1998-2002$ & 32 & 3.000 \\
\hline Freiburg-Vauban & urban rigeneration & 1993-2006 & 38 & 5.000 \\
\hline Freiburg-Rieselfeld & new development & 1993-2006 & 70 & 11.000 \\
\hline Stockholm-Hammarby Sjöstad & urban rigeneration & $1995-2015$ & 130 & 25.000 \\
\hline Helsinki-Kruunuvuorenranta & urban rigeneration & $2013-2020$ & 143 & 10.000 \\
\hline Hannover-Kronsberg & new development & $1993-2001$ & 150 & 15.000 \\
\hline Helsinki-Kalasatama & new development & $2010-2035$ & 200 & 18.000 \\
\hline Saragoza-Valdespartera & new development & $2001-2010$ & 243 & 10.000 \\
\hline Copenhagen-Ørestad & new development & 1995-on going & 310 & 20.000 \\
\hline Hamburg-Wilhelmsburg & $\begin{array}{l}\text { urban rigeneration/ } \\
\text { new development }\end{array}$ & 2006-2013 & 3500 & 56.000 \\
\hline
\end{tabular}




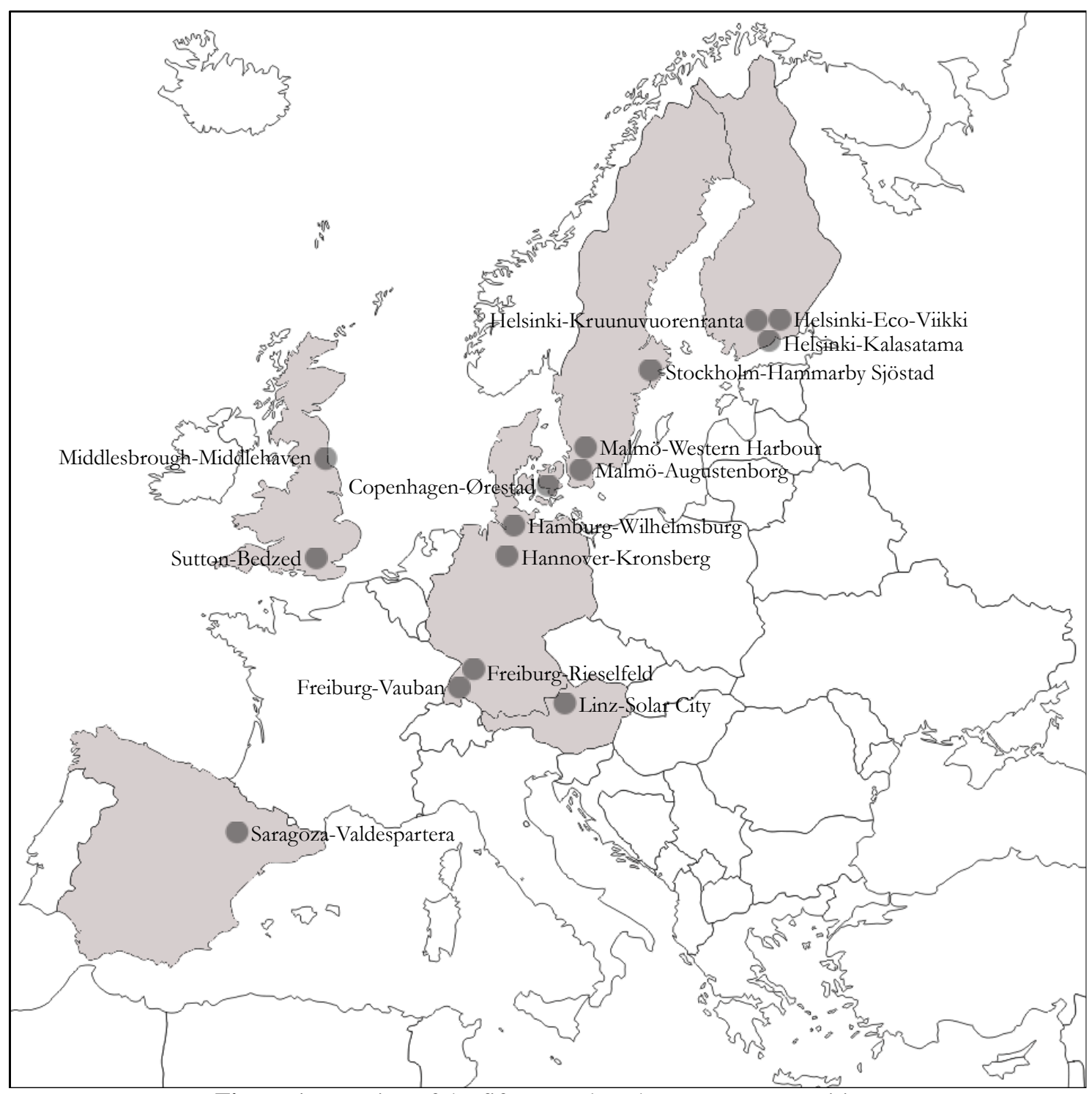

Figure 1. Location of the fifteen analyzed European green cities.

These specific conditions can affect the potential transferability of the UDS. Moreover local legislation, lack of experience of administrators to lead innovative actions also influence the suitability of UDS in these specific contexts.

A further step of the work was to set three levels of transferability: under any condition, under weak condition, under strong condition. Transferability of UDS is influenced by certain conditions that represent the obstacles to be overcame in order to transfer UDS into specific contexts through focused measures. Measures imply modification and changes to the system that can vary in terms of intervention scale and intensity of transformation. In this perspective, transferability can be considered as under weak condition when adaptation measures are sufficient to be undertaken, while transferability results under strong condition when transformation measures are necessary. The third step of the work was to perform the analysis of the transferability of UDS based on a survey carried out through interviews to Italian national experts in the field of urban planning. Questionnaires were sent out via email to 72 individuals including professors, researchers, professionals, practitioners and representatives of 
Physical Geography; Cartography; Geographic Information Systems \& Spatial Planing

\begin{tabular}{|c|c|c|c|}
\hline & $\begin{array}{l}\text { A) Stakeholders } \\
\text { involvement }\end{array}$ & $\begin{array}{l}\text { A1 } \\
\text { A2 } \\
\text { A3 }\end{array}$ & $\begin{array}{l}\text { Developers, contractors, planners and designers involvment } \\
\text { Local community involvment } \\
\text { Implementation of a community partecipated master plan }\end{array}$ \\
\hline & $\begin{array}{l}\text { B) Urban } \\
\text { development } \\
\text { management }\end{array}$ & $\begin{array}{l}\text { B1 } \\
\text { B2 } \\
\text { B3 } \\
\text { B4 }\end{array}$ & $\begin{array}{l}\text { Public control of urban development projects } \\
\text { Public control of financial and economic procedures } \\
\text { Allocation of a national/regional economic funds } \\
\text { Incentives for sustainable urban development, trading and services }\end{array}$ \\
\hline 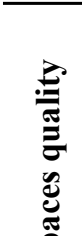 & $\begin{array}{l}\text { C) Control of } \\
\text { aesthetics and } \\
\text { planning rules } \\
\text { of seattlements }\end{array}$ & $\begin{array}{l}\mathrm{C} 1 \\
\mathrm{C} 2 \\
\mathrm{C} 3 \\
\mathrm{C} 4 \\
\mathrm{C} 5\end{array}$ & $\begin{array}{l}\text { Aesthetic components of architecture, mobility infrastructures and } \\
\text { technological systems } \\
\text { Urban development parameters } \\
\text { Urban morphology and building orientation } \\
\text { Mixed land uses } \\
\text { Private gardens and other open greenspaces }\end{array}$ \\
\hline 章 & $\begin{array}{l}\text { D) Public/private } \\
\text { facilities } \\
\text { and services }\end{array}$ & $\begin{array}{l}\text { D1 } \\
\text { D2 } \\
\text { D3 } \\
\text { D4 } \\
\text { D5 } \\
\end{array}$ & $\begin{array}{l}\text { High levels of green/blue public spaces } \\
\text { Localization of public/private facilities and services and new jobs } \\
\text { Public transportation stations/stops } \\
\text { Bike parking facilities for residents and visitors } \\
\text { Information centres }\end{array}$ \\
\hline \multirow{7}{*}{ 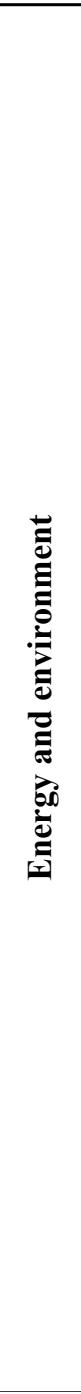 } & $\begin{array}{l}\text { E) Energy } \\
\text { efficiency } \\
\text { in the } \\
\text { sector } \\
\end{array}$ & $\begin{array}{l}\text { E1 } \\
\text { E2 } \\
\text { E3 } \\
\text { E4 }\end{array}$ & $\begin{array}{l}\text { Bioclimatic architecture and passive solar systems (wind cowls, } \\
\text { greenhouses, natural ventilation and lighting, building envelopes, etc.) } \\
\text { Household water saving/reuse systems } \\
\text { Solar and photovoltaic panels } \\
\text { Green roofs }\end{array}$ \\
\hline & \begin{tabular}{|l} 
F) Safeguard of \\
soils and \\
biodiversity
\end{tabular} & $\begin{array}{l}\text { F1 } \\
\text { F2 } \\
\text { F3 } \\
\text { F4 }\end{array}$ & $\begin{array}{l}\text { Conversion/reuse of abandoned/vacant urban areas } \\
\text { Contaminated soils restoration } \\
\text { Safeguard of current natural green areas } \\
\text { Water bodies restoration }\end{array}$ \\
\hline & $\begin{array}{l}\text { G) Water } \\
\text { management }\end{array}$ & $\begin{array}{l}\text { G2 } \\
\text { G3 } \\
\text { G4 }\end{array}$ & $\begin{array}{l}\text { Wastewater harvesting (irrigation, biomass production, treatment for } \\
\text { domestic use) } \\
\text { Rainwater harvesting (equilizers, urban drainage systems, underground } \\
\text { storage tanks) } \\
\text { Wastewater treatment plants (biogas, fertilizers, waste heat) } \\
\text { Purification/drinking water treatment plants }\end{array}$ \\
\hline & $\begin{array}{l}\text { H) Energy } \\
\text { management }\end{array}$ & $\begin{array}{l}\text { H1 } \\
\text { H2 } \\
\text { H4 } \\
\text { H5 } \\
\text { H6 } \\
\text { H7 }\end{array}$ & $\begin{array}{l}\text { Combined heat and power plants (based on renewable energy sources) } \\
\text { Incinerators } \\
\text { Wind turbines } \\
\text { Geothermal/marine power plants } \\
\text { Biomass power plants (wastewater, abandoned landfills, biomass wastes) } \\
\text { District heating grids } \\
\text { Closing of waste, water and energy cycles principles }\end{array}$ \\
\hline & \begin{tabular}{|l} 
I) Waste \\
management
\end{tabular} & $\begin{array}{l}\mathrm{I} 1 \\
\mathrm{I} 2 \\
\end{array}$ & $\begin{array}{l}\text { Waste sorting and collection systems } \\
\text { Bulky/tossic waste collection areas }\end{array}$ \\
\hline & & $\begin{array}{l}\mathrm{J} 1 \\
\mathrm{~J} 2 \\
\mathrm{~J} 3\end{array}$ & $\begin{array}{l}\text { Light metro/tram/ bus } \\
\text { Public waterborne transportation (water buse } \\
\text { Car pooling (biogas/elettric cars) }\end{array}$ \\
\hline & $\begin{array}{l}\text { J) Mobility } \\
\text { management }\end{array}$ & $\begin{array}{l}\text { J6 } \\
\text { J7 } \\
\text { J8 } \\
\text { J9 } \\
\text { J10 }\end{array}$ & $\begin{array}{l}\text { Pedestrian/bike paths and bike sharing systems } \\
\text { Integration of public and private transportation modes } \\
\text { Green and pedestrian/biker-friendly mobility infrastructures integrated } \\
\text { into roads } \\
\text { Green bridges/overpasses } \\
\text { Congestion charge } \\
\text { Limited parking lots beside the roads for private cars } \\
\text { Pedestrian zones }\end{array}$ \\
\hline
\end{tabular}

Table 2. Strategic categories (Procedural and economic aspects, Urban spaces quality, Energy and environment) sub-divided into ten different strategies (A-J) and 48 Urban Design Solutions (A1-J10).

local authorities identified as respondents who have the largest potential for advancing their own understanding [11]. Out of 72 invitations, 34 questionnaires were received. According to the six identified criteria, interviewees reported their own expert opinion on 
the potential transferability level of each UDS (identified by alphanumeric label XNo) within the boxes of three matrices (one matrix per each strategic category of UDS) (see Figures 2, 3, 4).

\section{RESULTS AND DISCUSSION}

The analysis of UDS identified 48 measures (from A1 to J10, see Table 2). Figures 2, 3, 4 show results of the proposed transferability method according to the most represented set of responses ( 7 respondents out of the 34 replied according to this setting). For each strategic category and criterion, percentages represent the number of UDS suitable to be transferred under any/weak/strong condition. Total transferability (100\% under any condition) occurs among UDS belonging to procedural an economic aspects and urban spaces quality categories (Figure 2). Looking at UDS per each criterion, the highest percentages of UDS suitable to be transferred under strong condition is referred to urban management criterion: 68\% (energy and environment category), 50\% (urban spaces quality category) and $29 \%$ (procedural and economic aspects category).

Considering all UDS within each matrix, transferability resulted in 95\% for procedural and economic aspects, $88 \%$ for urban spaces quality and $77 \%$ for energy and environment. These latter results derive from the assumption that transferability corresponds to transferability under any and weak condition. These values are calculated as average values according to the six criteria. Finally, $82 \%$ of UDS are suitable to be transferred (under any and weak conditions), while $18 \%$ of the UDS are transferable under strong condition and most of them belong to the energy and environment category. Even though the importance of these results, the transferability of UDS to urban contexts with different environmental, morphological, socio-economic and cultural conditions has not been systematically investigated. The proposed method explores the potential transferability of UDS to Southern Italy cities that are characterized by poor quality of urban environment and severe lack of experiences in the field of urban innovation strategies. The method is not context-dependent: the transferability criteria have been defined without specification of local features and can therefore be used in any geographical contexts. Nevertheless, the transferability method presents some limitations. Experts have been chosen according to the objectives of the study [12]. The six criteria and the three transferability levels, have been defined in a qualitative way without the use of quantitative indicators. This might affect the quality of the responses of the thirty-four interviewees, as they could provide their own opinion according to individual interpretation of criteria and levels of transferability. Results clearly show high levels of potential transferability of UDS from European green cities to southern Italy cities. Particularly, more than $80 \%$ of the total identified UDS result suitable to be transferred (under any/weak condition) through adaptation measures including changes of the local systems. Most remarkably, results highlight that transferability is more influenced by lack of urban management policies than climatic or geographical features of Italian contexts. 
Physical Geography; Cartography; Geographic Information Systems \& Spatial Planing

\begin{tabular}{|c|c|c|c|c|c|c|c|}
\hline \multicolumn{8}{|c|}{ Procedural and economic aspects } \\
\hline \multirow{3}{*}{ 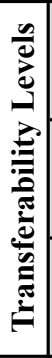 } & $\begin{array}{l}\text { under any } \\
\text { condition }\end{array}$ & $\begin{array}{l}\mathrm{A} 1 \rightarrow \mathrm{B} 4 \\
100 \%\end{array}$ & $\begin{array}{l}\mathrm{A} 1 \rightarrow \mathrm{B} 4 \\
\mathbf{1 0 0 \%}\end{array}$ & $\begin{array}{l}\mathrm{A} 1 \rightarrow \mathrm{B} 4 \\
\mathbf{1 0 0 \%}\end{array}$ & $\begin{array}{c}\mathrm{A} 1-\mathrm{A} 2-\mathrm{A} 3-\mathrm{B} 1- \\
\mathrm{B} 2 \\
\mathbf{7 1 \%}\end{array}$ & & \begin{tabular}{|c|}
$\mathrm{A} 1-\mathrm{A} 2-\mathrm{A} 3-\mathrm{B} 1-$ \\
$\mathrm{B} 2$ \\
$\mathbf{7 1 \%}$ \\
\end{tabular} \\
\hline & $\begin{array}{c}\text { under weak } \\
\text { condition }\end{array}$ & & & & $\begin{array}{l}\text { B3-B4 } \\
\mathbf{2 9 \%} \\
\end{array}$ & \begin{tabular}{|c|}
$\mathrm{A} 1-\mathrm{A} 2-\mathrm{A} 3-\mathrm{B} 1$ \\
$\mathrm{~B} 2$ \\
$\mathbf{7 1 \%}$ \\
\end{tabular} & $\begin{array}{c}\text { B3-B4 } \\
\mathbf{2 9 \%} \\
\end{array}$ \\
\hline & $\begin{array}{c}\text { under } \\
\text { strong } \\
\text { condition } \\
\end{array}$ & & & & & $\begin{array}{l}\text { B3-B4 } \\
\mathbf{2 9 \%} \\
\end{array}$ & \\
\hline & $\begin{array}{l}\text { ansferability } \\
\text { Criteria }\end{array}$ & $\begin{array}{c}\text { geographical- } \\
\text { climatic } \\
\text { features }\end{array}$ & $\begin{array}{c}\text { infrastructures } \\
\text { equipment/ } \\
\text { efficiency }\end{array}$ & $\begin{array}{c}\text { network } \\
\text { systems } \\
\text { equipment/ } \\
\text { efficiency }\end{array}$ & $\begin{array}{c}\text { norms and } \\
\text { regulations }\end{array}$ & $\begin{array}{c}\text { urban } \\
\text { management }\end{array}$ & $\begin{array}{c}\text { socio-cultural } \\
\text { features }\end{array}$ \\
\hline
\end{tabular}

Figure 2. Transferability matrix for Procedural and economic aspects category of UDS.

\begin{tabular}{|c|c|c|c|c|c|c|c|}
\hline \multicolumn{8}{|c|}{ Urban spaces quality } \\
\hline \multirow{3}{*}{ 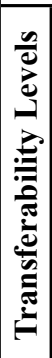 } & $\begin{array}{l}\text { under any } \\
\text { condition }\end{array}$ & $\begin{array}{l}\mathrm{C} 1 \rightarrow \mathrm{D} 5 \\
\mathbf{1 0 0 \%}\end{array}$ & \begin{tabular}{|c|} 
C1-C2-C3-D1- \\
C5-D5 \\
$\mathbf{6 0 \%}$
\end{tabular} & $\begin{array}{l}\mathrm{C} 1 \rightarrow \mathrm{D} 5 \\
\mathbf{1 0 0 \%}\end{array}$ & & & $\begin{array}{c}\mathrm{C} 2-\mathrm{C} 3-\mathrm{C} 4-\mathrm{C} 5- \\
\mathrm{D} 2 \\
\mathbf{5 0 \%}\end{array}$ \\
\hline & $\begin{array}{c}\text { under weak } \\
\text { condition }\end{array}$ & & $\begin{array}{l}\text { C4-D2 } \\
\mathbf{2 0 \%}\end{array}$ & & $\begin{array}{l}\mathrm{C} 1 \rightarrow \mathrm{D} 5 \\
\mathbf{1 0 0 \%}\end{array}$ & $\begin{array}{c}\mathrm{C} 2-\mathrm{C} 3-\mathrm{C} 4-\mathrm{C} 5- \\
\mathrm{D} 2 \\
\mathbf{5 0 \%}\end{array}$ & $\begin{array}{c}\text { C1-D1-D3-D4- } \\
\text { D5 } \\
\mathbf{5 0 \%}\end{array}$ \\
\hline & $\begin{array}{c}\text { under } \\
\text { strong } \\
\text { condition }\end{array}$ & & $\begin{array}{c}\text { D3-D4 } \\
\mathbf{2 0 \%}\end{array}$ & & & $\begin{array}{c}\text { C1-D1-D3-D4 } \\
\text { D5 } \\
\mathbf{5 0 \%}\end{array}$ & \\
\hline & $\begin{array}{l}\text { ansferability } \\
\text { Criteria }\end{array}$ & $\begin{array}{c}\text { geographical- } \\
\text { climatic } \\
\text { features }\end{array}$ & $\begin{array}{c}\text { infrastructures } \\
\text { equipment/ } \\
\text { efficiency }\end{array}$ & $\begin{array}{c}\text { network } \\
\text { systems } \\
\text { equipment/ } \\
\text { efficiency }\end{array}$ & $\begin{array}{l}\text { norms and } \\
\text { regulations }\end{array}$ & $\begin{array}{c}\text { urban } \\
\text { management }\end{array}$ & $\begin{array}{c}\text { socio-cultural } \\
\text { features }\end{array}$ \\
\hline
\end{tabular}

Figure 3. Transferability matrix for Urban spaces quality category of UDS.

\begin{tabular}{|c|c|c|c|c|c|c|c|}
\hline \multicolumn{8}{|c|}{ Energy and environment } \\
\hline \multirow{3}{*}{ 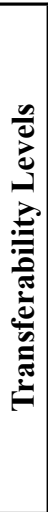 } & $\begin{array}{l}\text { under any } \\
\text { condition }\end{array}$ & \begin{tabular}{|c}
$\mathrm{E} 1 \rightarrow \mathrm{J} 10$ \\
excepted H3- \\
H4-H6 \\
$\mathbf{9 0 \%}$
\end{tabular} & \begin{tabular}{|c|} 
E3-F1-F2-F3- \\
F4-I1-I2-J8-J9- \\
J10 \\
$\mathbf{3 2 \%}$
\end{tabular} & $\begin{array}{c}\text { E1-E2-E3-E4- } \\
\text { F1-F2-F3-F4- } \\
\text { J1 } \rightarrow \text { J10 } \\
\mathbf{5 8 \%}\end{array}$ & & & $\begin{array}{c}\text { E1-E2-E3-E4- } \\
\text { F1-F2-F3-F4- } \\
\text { I1-I2 } \\
\mathbf{3 2} \%\end{array}$ \\
\hline & $\begin{array}{l}\text { under weak } \\
\text { condition }\end{array}$ & $\begin{array}{l}\text { H6 } \\
\mathbf{3 \%} \\
\end{array}$ & \begin{tabular}{|c|} 
E1-E2-E4-G1- \\
G2-G3-G4- \\
H1-H2-H3- \\
$\mathbf{4 5 \%}$
\end{tabular} & & $\begin{array}{c}\mathrm{E} 1 \rightarrow \mathrm{J} 10 \\
\mathbf{1 0 0 \%}\end{array}$ & $\begin{array}{c}\text { E1-E2-E3-E4- } \\
\text { F1-F2-F3-F4- } \\
\text { I1-I2 } \\
\mathbf{3 2 \%}\end{array}$ & $\begin{array}{c}\mathrm{G} 1 \rightarrow \mathrm{G} 4- \\
\mathrm{H} 1 \rightarrow \mathrm{H} 7- \\
\mathrm{J} 1 \rightarrow \mathrm{J} 10 \\
\mathbf{6 8 \%}\end{array}$ \\
\hline & $\begin{array}{c}\text { under } \\
\text { strong } \\
\text { condition }\end{array}$ & $\begin{array}{c}\mathrm{H} 3-\mathrm{H} 4 \\
\mathbf{7 \%}\end{array}$ & $\begin{array}{c}\mathrm{J} 1-\mathrm{J} 2-\mathrm{J} 3-\mathrm{J} 4-\mathrm{J} 5 \\
\mathrm{~J} 6-\mathrm{J} 7 \\
\\
\mathbf{2 3 \%}\end{array}$ & $\begin{array}{c}\text { G1-G2-G3- } \\
\text { G4-H1-H2- } \\
\text { H3-H4-H5- } \\
\text { H6-H7-I1-I2 } \\
\mathbf{4 2 \%}\end{array}$ & & $\begin{aligned} & \mathrm{G} 1 \rightarrow \mathrm{G} 4- \\
& \mathrm{H} 1 \rightarrow \mathrm{H} 7- \\
& \mathrm{J} 1 \rightarrow \mathrm{J} 10 \\
& \mathbf{6 8} \%\end{aligned}$ & \\
\hline & $\begin{array}{l}\text { nsferability } \\
\text { Criteria }\end{array}$ & $\begin{array}{c}\text { geographical- } \\
\text { climatic } \\
\text { features }\end{array}$ & $\begin{array}{c}\text { infrastructures } \\
\text { equipment/ } \\
\text { efficiency }\end{array} \mid$ & $\begin{array}{c}\text { network } \\
\text { systems } \\
\text { equipment/ } \\
\text { efficiency }\end{array}$ & $\begin{array}{c}\text { norms and } \\
\text { regulations }\end{array}$ & $\begin{array}{c}\text { urban } \\
\text { management }\end{array}$ & $\begin{array}{c}\text { socio-cultural } \\
\text { features }\end{array}$ \\
\hline
\end{tabular}

Figure 4. Transferability matrix for Energy and evinronment category of UDS.

\section{CONCLUSIONS}

Cities wishing to adopt measures of UDS should be able to assess their effectiveness in their local contexts and then look comprehensively at the conditions for their implementation [7]. The proposed method can be considered as a tool for assessing the transferability of UDS while identifying the main weaknesses of a local urban context. 
Furthermore, the application of this method could produce a considerable improvement in innovative urban planning practices. This is especially relevant in those urban contexts that are characterized by very low level of urban environmental quality and do not have yet targeted sustainable development strategies.

\section{ACKNOWLEDGMENTS}

This work has been conducted within the European SPECIAL project (Spatial Planning and Energy for Communities in All Landscapes) as an action in the framework of the Intelligent Energy Europe Programme (IEE) (www.special-eu.org).

\section{REFERENCES}

[1] European Environment Agency. Annual report 2010 and Environmental statement 2011, EEA, Copenhagen, 2010.

[2] European Union. Making our cities attractive and sustainable. How the EU contributes to improving the urban environment, Publications Office of the European Union, Luxembourg, 2010.

[3] Newman, P., Jennings, I. Cities as sustainable ecosystems - Principles and practices, Island Press, London, 2008.

[4] Latif S.A., Bidin Y.H., Awangb Z. Towards the Realization of Green Cities: The moderating role of the residents' education level, Procedia - Social and Behavioral Sciences, no. 85, pp. 646-652, 2013.

[5] Kahn, M.E. Green cities: Urban Growth and the Environment, Brookings Insti-tution Press, Washington DC, 2006.

[6] Inveroth S.P., Johansson S., Brandt N. The potential of the infrastructural system of Hammarby Sjöstad in Stockholm, Sweden, Energy Policy, no. 59, pp. 716-726, 2013.

[7] Macario, R., Marques, C. F. Transferability of sustainable urban mobility measures, Research in Transportation Economics, no. 22, pp. 146-156, 2008.

[8] Internationale Bauausstellung Hamburg (IBA), eds. Energy Atlas - Future Concept Renewable Wilhelmsburg, Jovis Verlag and IBA Hamburg GmbH, Hamburg, 2010.

[9] Knowles, R. D. Transit Oriented Development in Copenhagen, Denmark: from the Finger Plan to Ørestad, Journal of Transport Geography, no. 22, pp. 251-261, 2012.

[10] Martinico, F., La Rosa, D., Privitera, R. Green oriented urban development for urban ecosystem services provision in a medium sized city in southern Italy, iForest, no. 7(7), pp. 385-395, 2014.

[11] Kronenberg, J. Why not to green a city? Institutional barriers to preserving urban ecosystem services, Ecosystem Services, doi: 10.1016/j.ecoser.2014.07.002, 2014.

[12] Devers, K.J., Frankel, R.M. Study design in qualitative research-2: Sampling and data collection strategies, Education for Health, 13, pp. 263-271, 2000. 